Article

\title{
Degradation Kinetics and Disinfection By-Product Formation of Iopromide during UV/Chlorination and UV/Persulfate Oxidation
}

\author{
Chenyan Hu ${ }^{1,2}$, Qiangbing Wang ${ }^{1}$, Yi-Li Lin ${ }^{3, * \mathbb{D}}$, Yeye Zhu ${ }^{1}$, Cun Xiong ${ }^{1}$, Dandan Huang ${ }^{1}$ and Ling Xu $^{1}$ \\ 1 College of Environmental and Chemical Engineering, Shanghai Engineering Research Center of \\ Energy-Saving in Heat Exchange Systems, Shanghai University of Electric Power, Shanghai 200090, China; \\ huchenyan@126.com (C.H.); 18297422290@163.com (Q.W.); dflsz@outlook.com (Y.Z.); \\ cunxinxiaoniu@163.com (C.X.); 17826155927@163.com (D.H.); XuLing982@163.com (L.X.) \\ 2 Shanghai Institute of Pollution Control and Ecological Security, Shanghai 200092, China \\ 3 Department of Safety, Health and Environmental Engineering, National Kaohsiung University of Science and \\ Technology, Kaohsiung 824, Taiwan \\ * Correspondence: yililin@nkust.edu.tw
}

check for updates

Citation: Hu, C.; Wang, Q.; Lin, Y.-L.; Zhu, Y.; Xiong, C.; Huang, D.; Xu, L. Degradation Kinetics and Disinfection By-Product Formation of Iopromide during UV/Chlorination and UV/Persulfate Oxidation. Water 2022, 14, 503. https://doi.org/ $10.3390 / w 14030503$

Academic Editors: Bin $\mathrm{Xu}$, Tian-Yang Zhang and Wenjun Sun

Received: 30 December 2021

Accepted: 4 February 2022

Published: 8 February 2022

Publisher's Note: MDPI stays neutral with regard to jurisdictional claims in published maps and institutional affiliations.

Copyright: (C) 2022 by the authors Licensee MDPI, Basel, Switzerland. This article is an open access article distributed under the terms and conditions of the Creative Commons Attribution (CC BY) license (https:// creativecommons.org/licenses/by/ $4.0 /)$.

\begin{abstract}
As the detection of micropollutants in various water resources is commonly reported, developing an efficient technology to remove them to maintain water safety has become a major focus in recent years. The degradation kinetics of iopromide, one of a group of iodinated X-ray contrast media (ICM), using advanced oxidation processes of ultraviolet/chlorination $\left(\mathrm{UV} / \mathrm{Cl}_{2}\right)$ and UV/persulfate (UV/PS) oxidation were investigated in this research. The results show that iopromide degradation fitted pseudo-first-order kinetics, and the rate constants were calculated as $2.20( \pm 0.01) \times 10^{-1} \mathrm{~min}^{-1}$ and $6.08( \pm 0.10) \times 10^{-2} \mathrm{~min}^{-1}$ in $\mathrm{UV} / \mathrm{Cl}_{2}$ and $\mathrm{UV} / \mathrm{PS}$, respectively. In the two systems, the degradation rates were positively correlated with the initial concentrations of $\mathrm{HOCl}$ and PS, respectively. In the $\mathrm{UV} / \mathrm{Cl}_{2}$ system, the degradation rate of iopromide reached a maximum at $\mathrm{pH}$ 7, while in the UV/PS system, $\mathrm{pH}$ had only a slight effect on the degradation rate. Chloride in water had a negligible effect on iopromide degradation, whereas bromide inhibited iopromide degradation in the $\mathrm{UV} / \mathrm{Cl}_{2}$ system. The contributions of $\mathrm{UV}$ irradiation, $\bullet \mathrm{OH}$, and $\mathrm{RCS}$ to iopromide degradation during $\mathrm{UV} / \mathrm{Cl}_{2}$ treatment were calculated as $20.8 \%, 54.1 \%$, and $25.1 \%$, respectively. One carbonated and three nitrogenated disinfection by-products (C-DBP (chloroform) and N-DBPs (dichloroacetonitrile, trichloronitromethane, and trichloroacetone)) were detected at relatively high levels, along with three emerging iodinated DBPs (dichloroiodomethane, monochlorodiiodomethane, and triiodomethane). More $\mathrm{C}$ - and $\mathrm{N}$-DBPs were generated in the $\mathrm{UV} / \mathrm{Cl}_{2}$ and $\mathrm{UV} / \mathrm{PS}$ systems than in UV irradiation, while considerably higher I-DBPs were generated in UV irradiation than in the other two systems. Thus, it is essential to pay attention to DBP formation when $\mathrm{UV} / \mathrm{Cl}_{2}$ or UV/PS is used to treat iopromide in water. In order to better control the generation of carcinogenic and toxic I-DBPs, $\mathrm{Cl}_{2}$ or PS combined with UV should be adopted for iopromide degradation, instead of UV alone, for providing safe drinking water to the public.
\end{abstract}

Keywords: iodinated X-ray contrast media (ICM); kinetics; UV/chlorination; UV/persulfate oxidation; contribution of radicals; disinfection by-products (DBPs)

\section{Introduction}

Iodinated X-ray contrast media (ICM) such as iohexol, iopromide, iopamidol, iomeprol, and diatrizoate are widely used in radiological investigations for imaging body organs or blood vessels [1,2]. ICM cannot be effectively removed by conventional wastewater treatment processes and is discharged into the aqueous environment. Therefore, ICM have been detected in many rivers and streams (up to $\mu \mathrm{g} \mathrm{L}^{-1}$ in many countries) [3,4]. Iopromide is one of the most commonly used X-ray contrast media, and it remains almost unchanged 
after entering the body [5]. Iopromide has been detected in many water bodies [6], in concentrations ranging from $\mathrm{ng} \mathrm{L}^{-1}$ to $\mu \mathrm{g} \mathrm{L}^{-1}$ in wastewater and surface water [7]. It is reported that disinfectants can react with natural organic matter (NOM), bromide, and iodide during drinking-water treatment to form various disinfection by-products (DBPs) [8]. Although ICM themselves have no adverse effects on living creatures, they are thought to produce iodine, which results in the formation of emerging iodinated DBPs (I-DBPs), mainly including iodinated trihalomethanes (I-THMs) and iodo-acids (I-Acids) [9]. IDBPs are of higher cytotoxicity and genotoxicity than their chlorinated and brominated analogues, and therefore they have attracted widespread attention [10,11]. Moreover, IDBPs in drinking water can cause taste and odor problems, especially $\mathrm{CHI}_{3}$ which has a sensory threshold concentration of $1 \mu \mathrm{g} \mathrm{L}^{-1}$ [12]. A study indicated that iopamidol can react with chlorine to form trichloroacetic acid (TCAA), chloroform $\left(\mathrm{CHCl}_{3}\right)$, and dichloroiodomethane $\left(\mathrm{CHCl}_{2} \mathrm{I}\right)$ [13]. Therefore, it is essential to remove ICM from source water. The physical properties of iopromide are summarized in Table 1.

Table 1. The physical properties of iopromide.

Compound $\quad$ Molecular Formula

According to the previous literature, the degradation efficiency of the traditional oxidation process for ICM is not ideal [14-16]. With the development of advanced oxidation processes (AOPs), $\mathrm{UV} /$ chlorine $\left(\mathrm{UV} / \mathrm{Cl}_{2}\right)$ has been successfully applied for degrading micropollutants in recent years [17]. Other AOPs including $\mathrm{UV} / \mathrm{H}_{2} \mathrm{O}_{2}, \mathrm{UV} /$ persulfate (UV/PS), and UV/peroxymonosulfate can also effectively degrade ICM due to the generation of $\bullet \mathrm{OH}$ and $\bullet \mathrm{SO}_{4}{ }^{-}$possessing high redox potentials (1.8-2.7 and 2.5-3.1 V, respectively) [16]. Wu et al. investigated diatrizoate degradation by $\mathrm{UV} / \mathrm{Cl}_{2}$ and found that the reactive chlorine species (RCS) are major contributors to diatrizoate degradation [1]. Compared with $\mathrm{UV} / \mathrm{Cl}_{2}$, both iopamidol and diatrizoate could be degraded effectively by $\mathrm{UV} / \mathrm{H}_{2} \mathrm{O}_{2}$ [18]. UV/PS has been proven to be more efficient than $\mathrm{UV} / \mathrm{H}_{2} \mathrm{O}_{2}$ for diatrizoate degradation, and $\bullet \mathrm{SO}_{4}{ }^{-}$is the dominant reactive species in UV/PS oxidation. The secondorder rate constant of $\bullet \mathrm{SO}_{4}{ }^{-}$with diatrizoate was calculated as $1.90 \times 10^{9} \mathrm{M}^{-1} \mathrm{~s}^{-1}[19,20]$. However, to the best of our knowledge, there is currently no literature reporting the degradation kinetics of iopromide during $\mathrm{UV} / \mathrm{Cl}_{2}$ and $\mathrm{UV} / \mathrm{PS}$ AOPs.

Therefore, the purpose of this research was: (1) to investigate the degradation kinetics of iopromide during chlorination, $\mathrm{UV}$ photolysis, $\mathrm{UV} / \mathrm{Cl}_{2}$, and $\mathrm{UV} /$ persulfate, (2) to investigate the effects of different oxidant concentrations, $\mathrm{pH}$ values, and chloride and bromide concentrations on iopromide degradation, (3) to investigate the contribution of various radicals to the degradation of iopromide by $\mathrm{UV} / \mathrm{Cl}_{2}$, and (4) to evaluate the $\mathrm{C}-, \mathrm{N}-$, and I-DBPs formed in the sequential chlorine disinfection process.

\section{Materials and Methods}

\subsection{Chemicals and Regents}

All reagents used were at least analytical grade in this study. Iopromide ( $\geq 99 \%)$ was obtained from Pharmacopeia (Rockville, MD, USA). Sodium hypochlorite solution ( $\mathrm{NaClO}$, available chlorine: $4.00-4.99 \%$ ) was purchased from Sigma-Aldrich (St. Louis, MO, USA). 
Sodium persulfate $\left(\mathrm{Na}_{2} \mathrm{~S}_{2} \mathrm{O}_{8}\right)$ was purchased from Aladdin (Shanghai, China). Sodium hydroxide $(\mathrm{NaOH})$, sulfuric acid $\left(\mathrm{H}_{2} \mathrm{SO}_{4}\right)$, potassium dihydrogen phosphate $\left(\mathrm{KH}_{2} \mathrm{PO}_{4}\right)$, sodium acetate trihydrate $\left(\mathrm{CH}_{3} \mathrm{COONa} \cdot 3 \mathrm{H}_{2} \mathrm{O}\right)$, sodium chloride $(\mathrm{NaCl})$, sodium bromide $(\mathrm{NaBr})$, sodium bicarbonate $\left(\mathrm{NaHCO}_{3}\right)$, sodium thiosulfate $\left(\mathrm{Na}_{2} \mathrm{~S}_{2} \mathrm{O}_{3}\right)$, tert-butanol (TBA), and ethanol $(\mathrm{EtOH})$ were obtained from the Pharmaceutical Group Chemical Reagent $\mathrm{Co}$., Ltd. (Shanghai, China). Chromatographically pure reagent grade methanol $\left(\mathrm{CH}_{3} \mathrm{OH}\right)$ and methyl tert-butyl ether (MtBE) were acquired from J.T. Baker (Carpinteria, CA, USA). The I-THM standards including dichloriodomethane $\left(\mathrm{CHCl}_{2} \mathrm{I}\right)$, chlorodiiodomethane $\left(\mathrm{CHClI}_{2}\right)$, and triiodomethane $\left(\mathrm{CHI}_{3}\right)$ were obtained from CanSyn Chemical Corp. (Toronto, ON, Canada). Mixed C- and N- DBP standards including chloroform (CF), trichloroethane, trichloroethylene, tetrachloroethylene, dichloroacetonitrile (DCAN), trichloroacetonitrile (TCAN), trichloronitromethane (TCNM), and 1,1,1-trichloroacetone (1,1,1-TCP) were obtained from Sigma-Aldrich (St. Louis, MO, USA).

\subsection{Experimental Procedures}

A bench-scale reactor equipped with a low-pressure Hg UV mercury lamp (11 W, $254 \mathrm{~nm}, 4 \mathrm{P}-\mathrm{SE}$, Philips, Shanghai, China) was used to conduct the experiments. The UV intensity was determined as $1.12 \mathrm{~mW} / \mathrm{cm}^{2}$ using a UV radiometer (UV-C luxometer, Photoelectric Instrument Factory of Beijing Normal University, Beijing, China). Before the beginning of each experiment, the UV lamp was warmed up for $30 \mathrm{~min}$ to obtain a stable UV emission. A total of $100 \mathrm{~mL}$ of iopromide solution $(10 \mu \mathrm{M})$ was prepared for $\mathrm{UV} / \mathrm{Cl}_{2}$ and UV/PS oxidation experiments, with the $\mathrm{pH}$ adjusted to 7.0. Then, an appropriate amount of $\mathrm{NaClO}(100 \mathrm{mM})$ or PS $(1 \mathrm{M})$ was added into the reactor to achieve the desired dosage (25-200 $\mu \mathrm{M}$ for $\mathrm{NaClO}$ and 1-5 mM for PS). During each experiment, $1 \mathrm{~mL}$ of sample was withdrawn at certain time intervals and transferred to a high-performance liquid chromatography vial containing $30 \mu \mathrm{L}$ of $\mathrm{Na}_{2} \mathrm{~S}_{2} \mathrm{O}_{3}\left(0.1 \mathrm{M}\right.$ for $\left.\mathrm{UV} / \mathrm{Cl}_{2}\right)$ or excess methanol (for UV/PS) to terminate the reaction. All samples were analyzed using HPLC. Duplicate experiments were performed.

The contribution of radicals to the degradation of iopromide by $\mathrm{UV} / \mathrm{Cl}_{2}$ was examined by adding TBA or EtOH as a radical scavenger for the reaction, with an oxidant $(100 \mu \mathrm{M})$ /iopromide $(10 \mu \mathrm{M})$ molar ratio of 10 at $\mathrm{pH} 7$.

The experiments for DBP formation were conducted in $45 \mathrm{~mL}$ screw-cap glass vials with PTFE Sep under a headspace-free condition in a dark environment at $25 \pm 1{ }^{\circ} \mathrm{C}$. After $3 \mathrm{~d}$, the samples were quenched using $\mathrm{Na}_{2} \mathrm{~S}_{2} \mathrm{O}_{3}$ (for $\mathrm{UV} / \mathrm{Cl}_{2}$ ) or excess methanol (for $\mathrm{UV} / \mathrm{PS}$ ) and extracted using MtBE for DBP analysis using gas chromatography (GC).

\subsection{Analytical Methods}

The concentration of iopromide was analyzed using an HPLC system (Agilent 1200, Palo Alto, CA, USA) equipped with an XTerra MS column ( $5 \mu \mathrm{m}, 250 \mathrm{~mm} \times 4.6 \mathrm{~mm}$, Waters, Milford, CT, USA) and a UV spectrophotometer at the $242 \mathrm{~nm}$ wavelength. A $10 \mu \mathrm{L}$ sample was injected with $88 \%$ mobile phase and $12 \%$ acetic acid in ultra-pure water $(\mathrm{pH} 4)$ at a flow rate of $1.0 \mathrm{~mL} / \mathrm{min}$ at $30^{\circ} \mathrm{C}$. The detection limit of iopromide was $1 \mu \mathrm{M}$.

The $\mathrm{pH}$ values of the solutions were detected by using a regularly calibrated $\mathrm{pH}$ meter (FE20 FiveEasy, Mettler Toledo, Switzerland). The concentration of chlorine was measured using the N, N-diethyl-p-phenylenediamine (DPD) colorimetric method [21]. The concentration of persulfate was determined with a spectrophotometer (UV-2800, Unico Instruments Co., Ltd., Shanghai, China) at a wavelength of $352 \mathrm{~nm}$ [22].

The formation of DBPs was analyzed according to the US EPA Method 551.1 [23]. Samples were quenched and extracted using MtBE for the analysis using a GC (GC-2010 Plus, Shimadzu, Japan) equipped with an Rtx-5 column ( $30 \mathrm{~m} \times 0.25 \mathrm{~mm}$ internal diameter, $0.25 \mu \mathrm{m}$ film thickness, J\&W, Palo Alto, CA, USA). 


\section{Results and Discussion}

\subsection{Kinetics of Iopromide Degradation during UV Photolysis, $U V / C_{2}$, and UV/PS Oxidation}

In order to elucidate the correlation between iopromide degradation and time, different reaction systems including UV photolysis, chlorination, persulfate, $\mathrm{UV} / \mathrm{Cl}_{2}$ and $\mathrm{UV} /$ persulfate systems were investigated. As shown in Figure $1, \mathrm{UV} / \mathrm{Cl}_{2}$ could degrade iopromide most effectively, followed by UV/PS and UV photolysis, but not chlorination and persulfate alone. The degradation fitted pseudo-first-order kinetics well, as expressed in Equation (1):

$$
\frac{-\mathrm{d}[\text { iopromide }]}{\mathrm{dt}}=\mathrm{k}_{\mathrm{obs}}[\text { iopromide }]_{\mathrm{t}}
$$

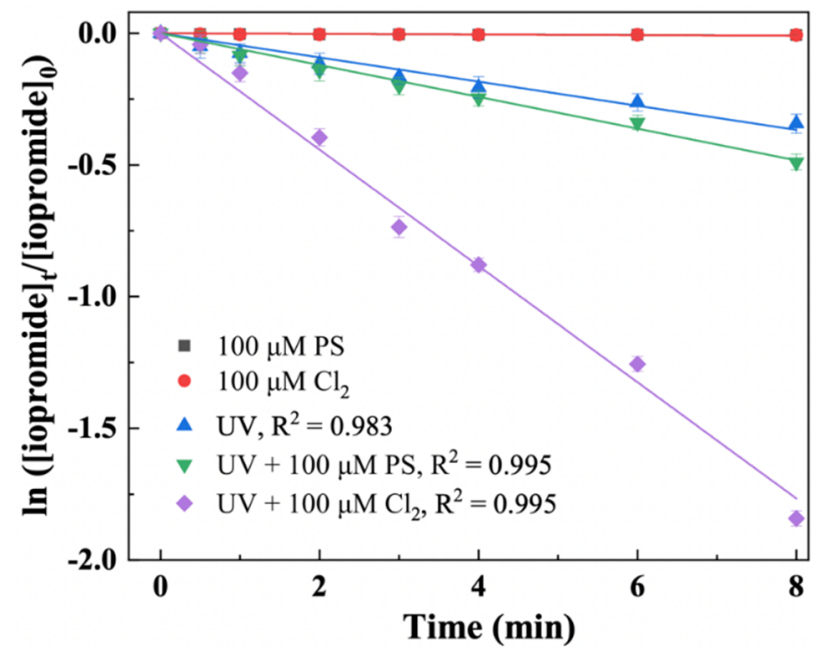

Figure 1. Pseudo-first-order kinetics plot of iopromide degradation during chlorine, persulfate, $\mathrm{UV}$ photolysis, $\mathrm{UV} / \mathrm{Cl}_{2}$, and UV/PS oxidation. Experimental conditions: [iopromide] $0=10 \mu \mathrm{M}$, $[\mathrm{HOCl}]_{0}=$ [persulfate $]_{0}=100 \mu \mathrm{M}, \mathrm{UV}$ intensity $=1.12 \mathrm{~mW} \mathrm{~cm}^{-2}$, [phosphate buffer $]_{0}=10 \mathrm{mM}$, $\mathrm{pH}=7$, and temperature $=25^{\circ} \mathrm{C}$.

By using the data in Figure 1, the $\mathrm{k}_{\mathrm{obs}}$ values of iopromide degradation during UV photolysis, $\mathrm{UV} / \mathrm{Cl}_{2}$, and UV /PS can be calculated as $4.58( \pm 0.02) \times 10^{-2}, 2.20( \pm 0.01) \times 10^{-1}$, and $6.08( \pm 0.10) \times 10^{-2} \mathrm{~min}^{-1}$, respectively. The $\mathrm{k}_{\mathrm{obs}}$ values for $\mathrm{UV} / \mathrm{Cl}_{2}$ and $\mathrm{UV} / \mathrm{PS}$ were greater than the value for UV irradiation alone due to the generation of $\bullet \mathrm{OH}, \bullet \mathrm{SO}_{4}{ }^{-}$, and RCS [24].

3.2. Effects of Different Initial HOCl and PS Concentrations on Iopromide Degradation by $\mathrm{UV} / \mathrm{Cl}_{2}$ and UV/PS Oxidation

The effects of oxidant concentration on the degradation of iopromide in the $\mathrm{UV} / \mathrm{Cl}_{2}$ and UV/PS processes were studied (Figure S1). As displayed in Figure 2a, the degradation of iopromide with different initial chlorine concentrations during $\mathrm{UV} / \mathrm{Cl}_{2}$ fitted a pseudo-first-order kinetics model well $\left(\mathrm{R}^{2}>0.99\right)$. The $\mathrm{k}_{\mathrm{obs}}$ of iopromide increased from $4.58( \pm 0.20) \times 10^{-2}$ to $3.47( \pm 0.11) \times 10^{-1} \mathrm{~min}^{-1}$ as the chlorine concentration increased from 0 (UV alone) to $200 \mu \mathrm{M}$. The lower-left insert in Figure 2a shows a linear relationship between $\mathrm{k}_{\mathrm{obs}}$ and the chlorine concentration, with $\mathrm{R}^{2}=0.973$, which indicates that the rate of iopromide degradation during $\mathrm{UV} / \mathrm{Cl}_{2}$ is first order with respect to chlorine concentration. As the chlorine concentration increases, free chlorine can produce a series of radicals including $\bullet \mathrm{OH}$ and RCS under UV irradiation, enhancing the rate of iopromide degradation, as expressed in Equations (2) and (3):

$$
\begin{gathered}
\frac{-\mathrm{d}[\text { iopromide }]}{\mathrm{dt}}=\mathrm{k}_{\mathrm{UV} / \text { chlorine }}[\text { iopromide }]_{\mathrm{t}} \\
=\mathrm{k}_{\mathrm{UV}}[\text { iopromide }]_{\mathrm{t}}+\mathrm{k}_{\bullet \mathrm{OH}}[\text { iopromide }]_{\mathrm{t}}+\mathrm{k}_{\mathrm{RCS}}[\text { iopromide }]_{\mathrm{t}} \\
\mathrm{k}_{\mathrm{UV} / \text { chlorine }}=\mathrm{k}_{\mathrm{UV}}+\mathrm{k}_{\bullet} \mathrm{OH}+\mathrm{k}_{\mathrm{RCS}}
\end{gathered}
$$


where $\mathrm{k}_{\mathrm{uv} / \text { chlorine }}$ and $\mathrm{k}_{\mathrm{uv}}$ represent the observed pseudo-first-order reaction rate constants of iopromide degradation during $\mathrm{UV} / \mathrm{Cl}_{2}$ and $\mathrm{UV}$ photolysis, respectively, and $\mathrm{k}_{\bullet} \mathrm{OH}$ and $\mathrm{k}_{\mathrm{RCS}}$ represent the pseudo-first-order reaction rate constants of iopromide degradation by $\bullet \mathrm{OH}$ and RCS, respectively.
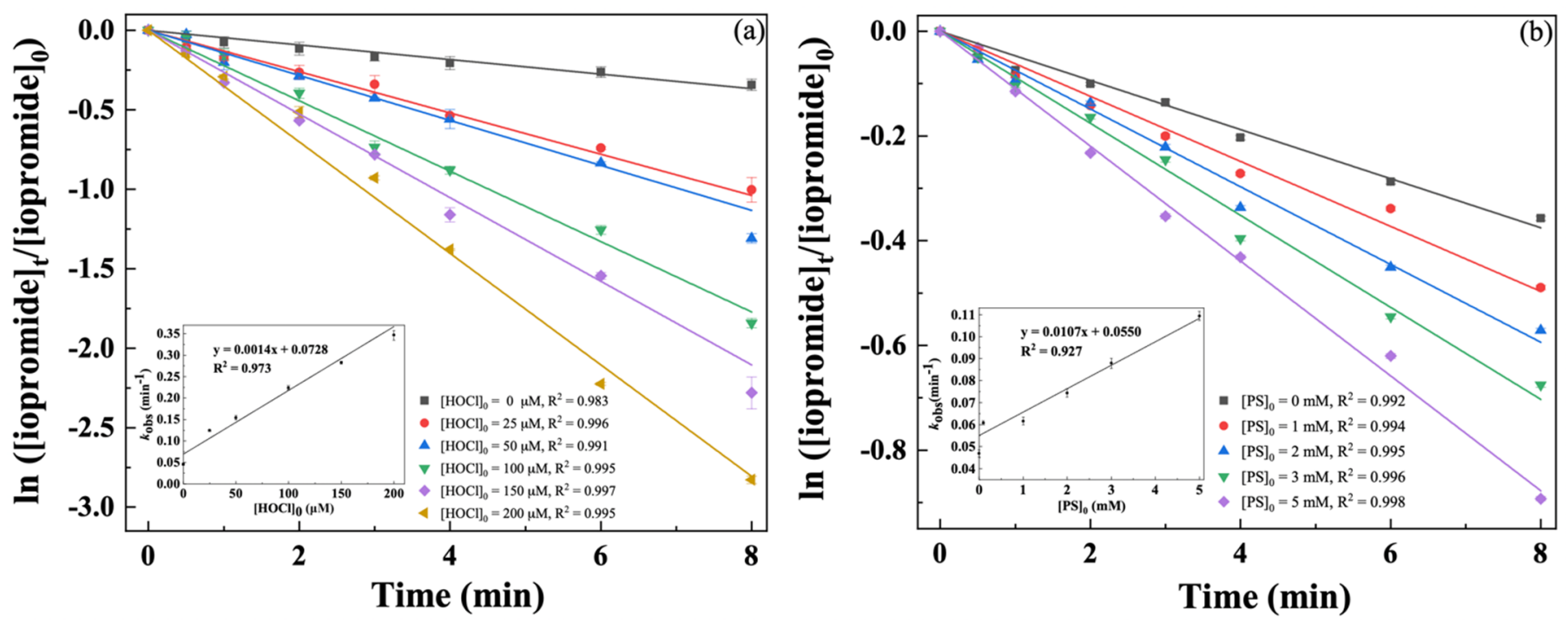

Figure 2. Effects of different oxidant concentrations on iopromide degradation during (a) $U V / \mathrm{Cl}_{2}$ and (b) UV/PS oxidation. Experimental conditions: [iopromide] $]_{0}=10 \mu \mathrm{M}, \mathrm{UV}$ intensity $=1.12 \mathrm{~mW} \mathrm{~cm}^{-2}$, [phosphate buffer $]_{0}=10 \mathrm{mM}, \mathrm{pH}=7$, and temperature $=25^{\circ} \mathrm{C}$. Error bars represent one standard deviation of duplicate measurements.

On the other hand, iopromide degradation also fitted pseudo-first-order kinetics well at different PS concentrations, as displayed in Figure $2 b$. The $k_{\text {obs }}$ for iopromide degradation increased considerably from $6.14( \pm 0.18) \times 10^{-2}$ to $1.09( \pm 0.02) \times 10^{-1} \mathrm{~min}^{-1}$ as the PS dosage increased from $1 \mathrm{mM}$ to $5 \mathrm{mM}$, by increasing the formation of oxidizing radicals $\left(\bullet \mathrm{OH}\right.$ and $\left.\bullet \mathrm{SO}_{4}{ }^{-}\right)$, as shown in Equations (4) and (5) [25].

$$
\begin{gathered}
\mathrm{S}_{2} \mathrm{O}_{8}{ }^{2-}+\mathrm{hv} \rightarrow 2 \bullet \mathrm{SO}_{4}{ }^{-} \\
\bullet \mathrm{SO}_{4}{ }^{-}+\mathrm{OH}^{-} \rightarrow \mathrm{SO}_{4}{ }^{2-}+\bullet \mathrm{OH}
\end{gathered}
$$

\subsection{Contributions of Radicals to Iopromide Degradation by $\mathrm{UV} / \mathrm{Cl}_{2}$}

It has been reported that during $\mathrm{UV} / \mathrm{Cl}_{2}, \bullet \mathrm{OH}$ and $\bullet \mathrm{Cl}$ were the dominant radicals for the degradation of benzoic acid, while the effects of other reactive species such as $\bullet \mathrm{Cl}_{2}{ }^{-}$ and $\bullet \mathrm{O}^{-}$were negligible [26]. To determine the contributions of radicals in iopromide degradation in the $\mathrm{UV} / \mathrm{Cl}_{2}$ system, radical scavenging experiments were performed with the addition of excessive TBA and $\mathrm{EtOH}$. TBA reacts with $\bullet \mathrm{Cl}$ with a rate constant of $1.8 \times 10^{10} \mathrm{M}^{-1} \mathrm{~min}^{-1}$, whereas the rate constant for the reaction of TBA with $\bullet \mathrm{Cl}_{2}{ }^{-}$ is $2.1 \times 10^{4} \mathrm{M}^{-1} \mathrm{~min}^{-1}[27,28]$. As shown in Figure 3, the $\mathrm{k}_{\mathrm{obs}}$ values of iopromide during $\mathrm{UV} / \mathrm{Cl}_{2}$ decreased to $1.64( \pm 0.06) \times 10^{-1}$ and $1.01( \pm 0.02) \times 10^{-1} \mathrm{~min}^{-1}$ in the presence of $100 \mathrm{mM} \mathrm{TBA}$ and $\mathrm{EtOH}$, respectively, while the degradation of iopromide dropped from $84.2 \%$ to $74.7 \%$ and $56.7 \%$, respectively, after 8 min of reaction time. As displayed in Figure 4 , the calculated contributions of UV irradiation, $\bullet \mathrm{OH}$, and RCS to the degradation of iopromide were $20.8 \%, 54.1 \%$, and $25.1 \%$, respectively (Equations (6)-(8)). The radicals formed in the $\mathrm{UV} / \mathrm{Cl}_{2}$ system enhanced the iopromide degradation. It has been reported that the rate constant of the reaction of $\bullet \mathrm{OH}$ with iopromide was $3.34 \pm(0.14) \times 10^{9} \mathrm{M}^{-1} \mathrm{~s}^{-1}$ using $\gamma$-irradiation [29], while there has been little research on the rate constant of $\bullet \mathrm{Cl}$ 
with iopromide. Therefore, the role of $\bullet \mathrm{Cl}$ should not be neglected in the degradation of iopromide.

$$
\begin{aligned}
& \left(\mathrm{k}_{\mathrm{obs}, \mathrm{UV}} / \mathrm{k}_{\mathrm{obs}, \mathrm{UV} / \mathrm{Cl}_{2}}\right) \times 100 \% \\
& \left(\mathrm{k}_{\mathrm{obs}, \mathrm{UV} / \mathrm{Cl}_{2}}-\mathrm{k}_{\mathrm{obs}, \mathrm{EtOH}}\right) / \mathrm{k}_{\mathrm{obs}, \mathrm{UV} / \mathrm{Cl}_{2}} \times 100 \% \\
& \left(1-\left(\mathrm{k}_{\mathrm{obs}, \mathrm{UV}} / \mathrm{k}_{\mathrm{obs}, \mathrm{UV} / \mathrm{Cl}_{2}}\right)-\left(\mathrm{k}_{\mathrm{obs}, \mathrm{UV} / \mathrm{Cl}_{2}}-\mathrm{k}_{\mathrm{obs}, \mathrm{EtOH}}\right) / \mathrm{k}_{\mathrm{obs}, \mathrm{UV} / \mathrm{Cl}_{2}}\right) \times 100 \%
\end{aligned}
$$

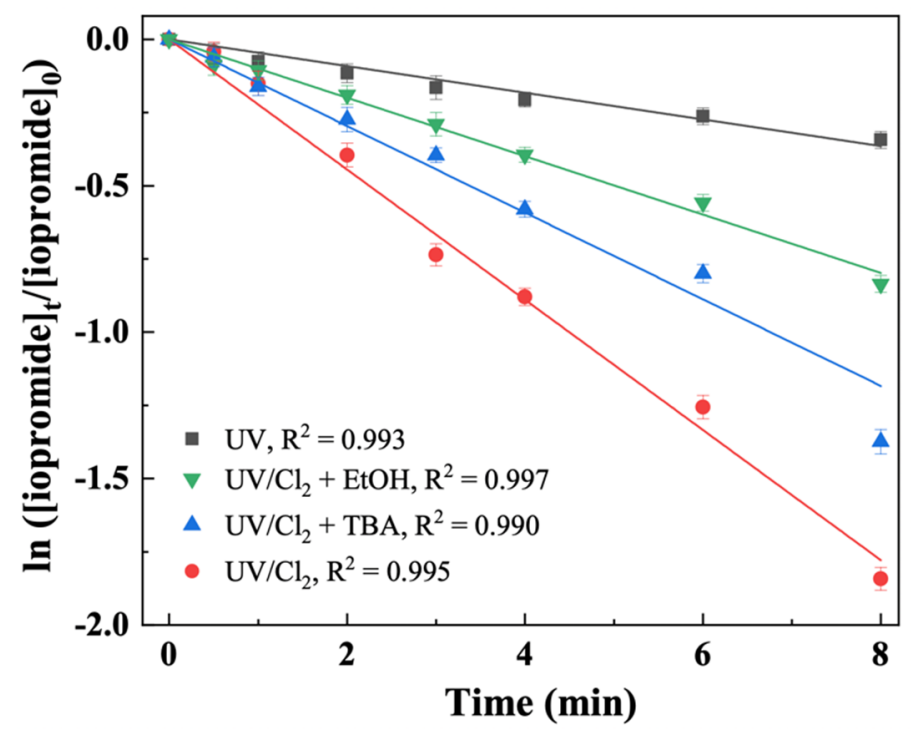

Figure 3. Effects of two radical scavengers on iopromide degradation during $\mathrm{UV} / \mathrm{Cl}_{2}$. Experimental conditions: $[\text { iopromide }]_{0}=10 \mu \mathrm{M},[\mathrm{HOCl}]_{0}=100 \mu \mathrm{M},[\mathrm{TBA}]_{0}=[\mathrm{EtOH}]_{0}=100 \mathrm{mM}$, $\mathrm{UV}$ intensity $=1.12 \mathrm{~mW} \mathrm{~cm}^{-2}$, [phosphate buffer $]_{0}=10 \mathrm{mM}, \mathrm{pH}=7$, and temperature $=25^{\circ} \mathrm{C}$.

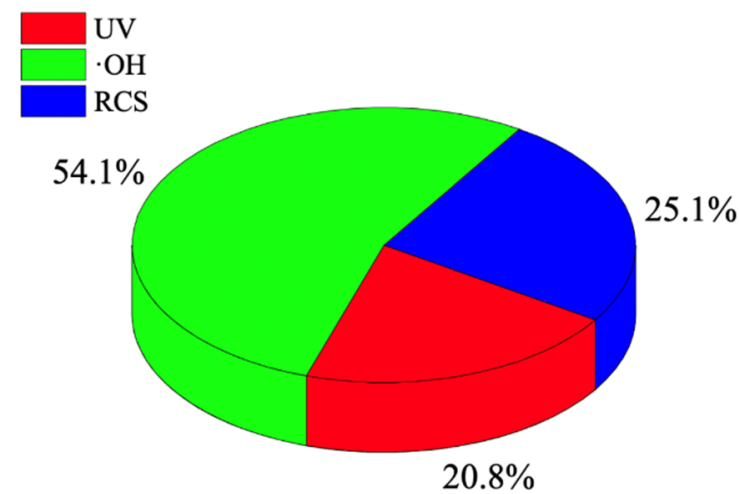

Figure 4. Contribution rates of different radicals to iopromide degradation during $\mathrm{UV} / \mathrm{Cl}_{2}$. Experimental conditions: $[\text { iopromide }]_{0}=10 \mu \mathrm{M},[\mathrm{HOCl}]_{0}=100 \mu \mathrm{M},[\mathrm{TBA}]_{0}=[\mathrm{EtOH}]_{0}=100 \mathrm{mM}$, UV intensity $=1.12 \mathrm{~mW} \mathrm{~cm}^{-2}$, [phosphate buffer $]_{0}=10 \mathrm{mM}, \mathrm{pH}=7$, and temperature $=25^{\circ} \mathrm{C}$.

\subsection{Effects of Solution $\mathrm{pH}$ on Iopromide Degradation by $\mathrm{UV} / \mathrm{Cl}_{2}$ and $\mathrm{UV} / \mathrm{PS}$}

As illustrated in Figure 5a, at $\mathrm{pH} 7$ the rate of iopromide degradation in $\mathrm{UV} / \mathrm{Cl}_{2}$ reached a maximum and then decreased as the $\mathrm{pH}$ increased further to $\mathrm{pH}$ 9. In the $\mathrm{UV} / \mathrm{Cl}_{2}$ system, chlorine is dissociated into $\mathrm{OCl}^{-}$, which can form $\bullet \mathrm{OH}$ and $\bullet \mathrm{Cl}$ under $\mathrm{UV}$ irradiation (Equations (9) and (10)) [26,30]. As the solution $\mathrm{pH}$ changed, chlorine speciations were affected [31]. The acid dissociation constant (pKa) of $\mathrm{HOCl}$ is 7.5 , so the solution was dominated by $\mathrm{HClO}$ at $\mathrm{pH} \leq 7.5$. Compared to $\mathrm{OCl}^{-}, \mathrm{HOCl}$ is more effective for inactivating Escherichia coli and other pathogens in drinking water [32]. However, in the previous experiments, chlorination could not degrade iopromide effectively (Figure 1 at $\mathrm{pH}$ 7). Although $\mathrm{HOCl}$ has no degradation effect on iopromide, the difference in $\mathrm{HOCl} / \mathrm{OCl}^{-}$ 
distribution in water can affect the UV absorbance and quantum yield of the solution. [33]. Under $254 \mathrm{~nm}$ irradiation, the quantum yields of $\mathrm{HOCl}$ and $\mathrm{OCl}^{-}$photolysis at room temperature were determined to be 1.45 and 0.97 , respectively [34].

$$
\begin{gathered}
\mathrm{HOCl} \Leftrightarrow \mathrm{OCl}^{-}+\mathrm{H}^{+} \\
\mathrm{HOCl} / \mathrm{OCl}^{-} \rightarrow \bullet \mathrm{OH} / \bullet \mathrm{O}^{-}+\bullet \mathrm{Cl}
\end{gathered}
$$
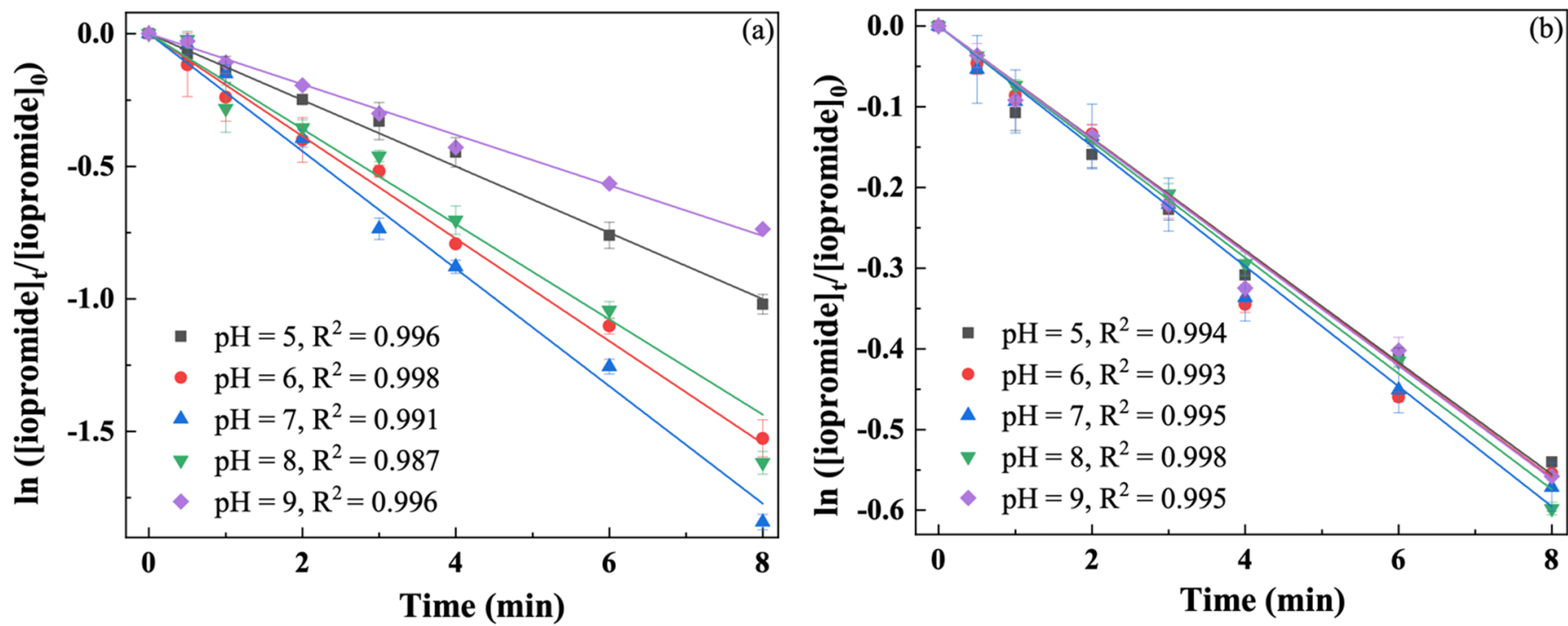

Figure 5. Effects of different $\mathrm{pH}$ values on iopromide degradation during (a) $\mathrm{UV} / \mathrm{Cl}_{2}$ and (b) UV/PS oxidation. Experimental conditions: [iopromide $]_{0}=10 \mu \mathrm{M},[\mathrm{HOCl}]_{0}=[\mathrm{PS}]_{0}=100 \mu \mathrm{M}$, $\mathrm{UV}$ intensity $=1.12 \mathrm{~mW} \mathrm{~cm}^{-2}$, [phosphate buffer $]_{0}=10 \mathrm{mM}$, and temperature $=25^{\circ} \mathrm{C}$.

In Figure 5b, pH had a minor effect on the degradation of iopromide via UV/PS oxidation, which can be explained as follows. (1) According to the literature, under acidic and neutral conditions $\bullet \mathrm{SO}_{4}{ }^{-}$is the predominant radical [35]. (2) At $\mathrm{pH} \geq 7$, the $\bullet \mathrm{SO}_{4}{ }^{-}$ can be converted to $\bullet \mathrm{OH}$ according to Equations (11) and (12) [36]. The redox potential of $\bullet \mathrm{SO}_{4}{ }^{-}$and $\bullet \mathrm{OH}$ is $2.5-3.1 \mathrm{~V}$ and $1.8-2.7 \mathrm{~V}$, respectively [37]. Although the difference from Figure $5 b$ is not significant, the reaction rate constant under alkaline conditions is smaller.

$$
\begin{gathered}
\bullet \mathrm{SO}_{4}{ }^{-}+\mathrm{H}_{2} \mathrm{O} \rightarrow \mathrm{SO}_{4}{ }^{2-}+\bullet \mathrm{OH}+\mathrm{H}^{+} \\
\bullet \mathrm{SO}_{4}{ }^{-}+\mathrm{OH}^{-} \rightarrow \mathrm{SO}_{4}{ }^{2-}+\bullet \mathrm{OH}
\end{gathered}
$$

\subsection{Effects of Inorganic Ions on Iopromide Degradation by UV/Chlorination}

$\mathrm{Cl}^{-}$exists widely in the water matrix, with concentrations ranging from 0 to $20 \mathrm{mM}$ in surface water and wastewater effluent [38]. Thus, in this study, the influence of chloride on the degradation of iopromide was studied at concentrations of 0-20 mM. As seen in Figure 6a, the presence of $\mathrm{Cl}^{-}$has a negligible effect on the degradation of iopromide. The explanation for this phenomenon involves the reactions between $\mathrm{Cl}^{-}$and $\bullet \mathrm{OH}$ to form $\bullet \mathrm{ClOH}^{-}$[39]. In addition, $\mathrm{Cl}^{-}$can react with $\bullet \mathrm{Cl}$ to produce $\bullet \mathrm{Cl}_{2}^{-}$[40]. The produced $\bullet \mathrm{ClOH}^{-}$and $\bullet \mathrm{Cl}_{2}^{-}$can be decomposed into $\bullet \mathrm{OH}$ and $\bullet \mathrm{Cl}$ in a reversible manner [41]. 

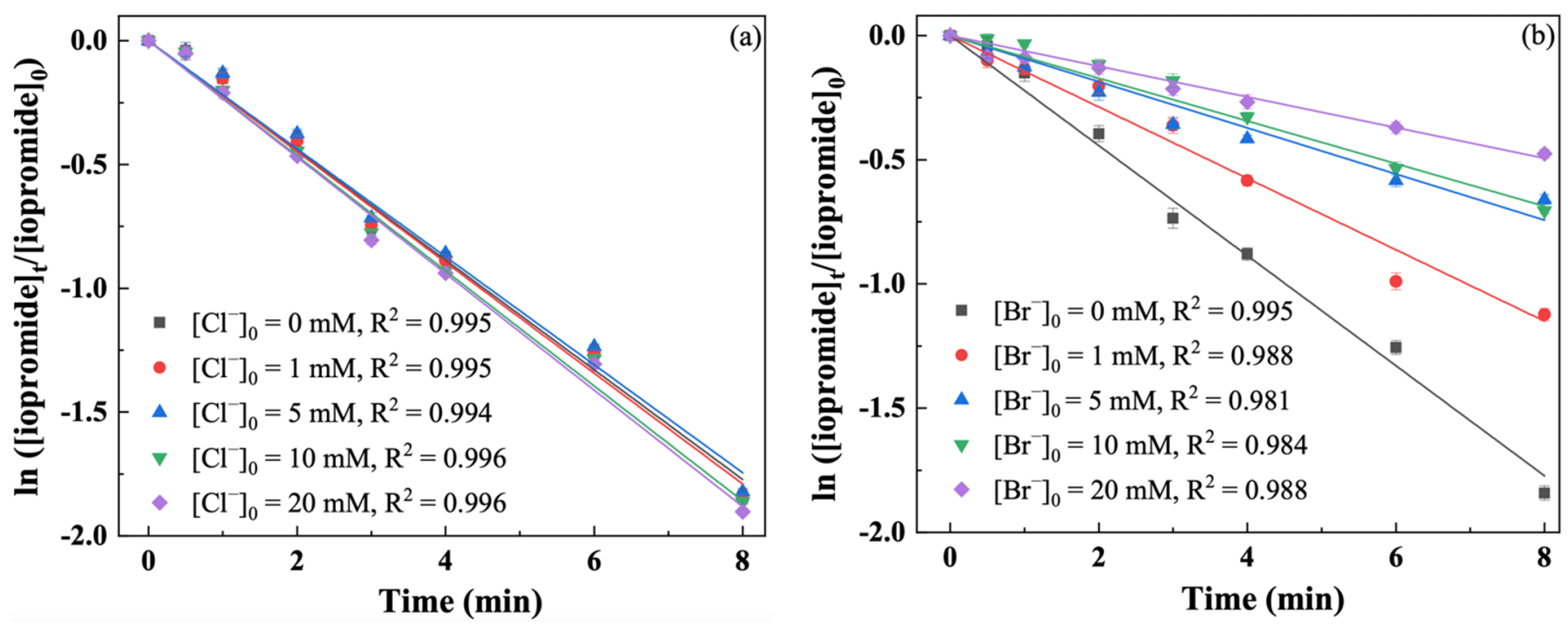

Figure 6. Effects of (a) chloride and (b) bromide concentrations on the degradation of iopromide during UV/chlorination. Experimental conditions: [iopromide $]_{0}=10 \mu \mathrm{M},[\mathrm{HOCl}]_{0}=100 \mu \mathrm{M}$, $\mathrm{UV}$ intensity $=1.12 \mathrm{~mW} \mathrm{~cm}^{-2}$, [phosphate buffer $]_{0}=10 \mathrm{mM}, \mathrm{pH}=7$, and temperature $=25^{\circ} \mathrm{C}$.

$\mathrm{Br}^{-}$can also compete for radicals with the target compounds. The concentration range of $\mathrm{Br}^{-}$in this study was $0-20 \mathrm{mM}$. As displayed in Figure $6 \mathrm{~b}$, the degradation of iopromide was inhibited due to the presence of $\mathrm{Br}^{-}$, because bromide can react rapidly with $\bullet \mathrm{OH}$ to form $\bullet \mathrm{BrOH}^{-}$and act like a radical scavenger. The rate constant of the reaction of $\mathrm{Br}^{-}$with $\bullet \mathrm{OH}$ is $6.6 \times 10^{11} \mathrm{M}^{-1} \mathrm{~min}^{-1}$ [42]. Accordingly, the $\mathrm{k}_{\mathrm{obs}}$ value decreased from $2.20( \pm 0.01) \times 10^{-1} \mathrm{~min}^{-1}$ to $6.24( \pm 0.24) \times 10^{-2} \mathrm{~min}^{-1}$ as the bromide concentration increased from 0 to $20 \mathrm{mM}$.

\subsection{Formation of DBPs during Iopromide Degradation in Different Oxidation Systems}

In order to evaluate the formation of DBPs after iopromide oxidation in the sequential chlorine disinfection process, which is the most commonly applied disinfection process, various $\mathrm{C}-,^{\mathrm{N}-}$, and I-DBPs were analyzed. The results are displayed in Figure 7. In the three systems, one C-DBP $\left(\mathrm{CHCl}_{3}\right)$ and three N-DBPs (dichloroacetonitrile (DCAN), trichloronitromethane (TCNM), and trichloroacetone (TCAN)) were detected at high concentrations. The concentrations of $\mathrm{CHCl}_{3}$ and TCNM after $\mathrm{UV} / \mathrm{Cl}_{2}$ were greater than those for UV irradiation alone, while the concentrations of DCAN and TCAN were similar in the UV and $\mathrm{UV} / \mathrm{Cl}_{2}$ systems. In the $\mathrm{UV} / \mathrm{Cl}_{2}$ system, the amounts of TCM and TCNM were greater than for UV irradiation. A similar phenomenon was also observed in the research of Qin et al. for the treatment of ronidazole in a $\mathrm{UV} / \mathrm{Cl}_{2}$ system [43]. The concentrations of $\mathrm{C}$ - and $\mathrm{N}-\mathrm{DBPs}$ in the UV/PS system were lower than those for UV irradiation and the UV/Cl 2 system. On the other hand, three I-DBPs were detected (dichloromonoiodomethane $\left(\mathrm{CHCl}_{2} \mathrm{I}\right)$, chlorodiiodomethane $\left(\mathrm{CHClI}_{2}\right)$, and triiodomethane $\left.\left(\mathrm{CHI}_{3}\right)\right)$, and much higher amounts were formed in the system with UV alone compared to the $\mathrm{UV} / \mathrm{Cl}_{2}$ and $\mathrm{UV} / \mathrm{PS}$ oxidation systems. Because the benzene ring of iopromide contains iodine atoms, the organic iodine can be a precursor of I-DBPs in the drinking-water chlorine disinfection process [44]. The reason for the higher amounts of I-DBPs formed with $\mathrm{UV}$ alone than in $\mathrm{UV} / \mathrm{Cl}_{2}$ and $\mathrm{UV} / \mathrm{PS}$ can be explained by the conversion of $\mathrm{I}^{-}$into stable $\mathrm{IO}_{3}^{-}$in $\mathrm{UV} / \mathrm{Cl}_{2}$ and $\mathrm{UV} / \mathrm{PS}$ [45]. Accordingly, $\mathrm{UV} / \mathrm{Cl}_{2}$ and UV/PS oxidation can reduce the generation of toxic I-DBPs effectively in the sequential chlorine disinfection process after iopromide degradation compared to UV irradiation, which is beneficial for providing safe drinking water to the public. 


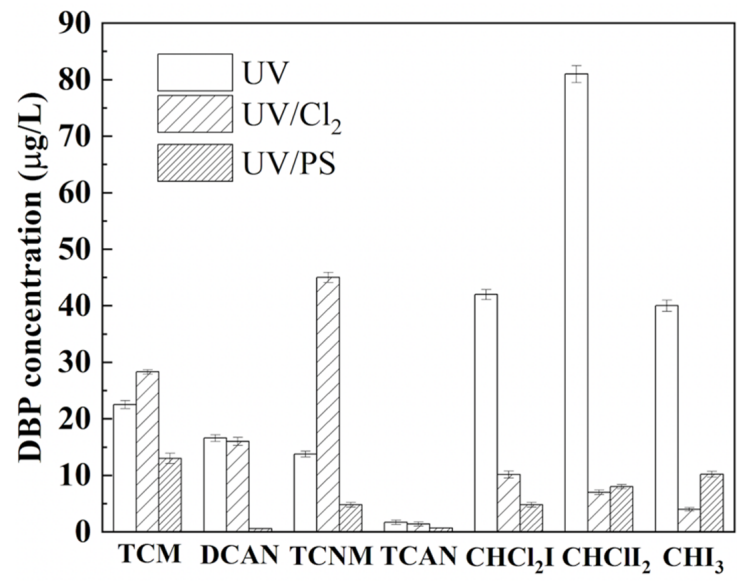

Figure 7. Formation of DBPs after $\mathrm{UV}$ irradiation, $\mathrm{UV} / \mathrm{Cl}_{2}$, and $\mathrm{UV} / \mathrm{PS}$ oxidation of iopromide. Experimental conditions: [iopromide $]_{0}=10 \mu \mathrm{M}$, [chlorine $]_{0}=[\text { persulfate }]_{0}=100 \mu \mathrm{M}$, $\mathrm{UV}$ intensity $=1.12 \mathrm{~mW} \mathrm{~cm}^{-2}$, [phosphate buffer $]_{0}=10 \mathrm{mM}, \mathrm{pH}=7$, incubation time $=3 \mathrm{~d}$, and temperature $=25^{\circ} \mathrm{C}$. Error bars represent one standard deviation of duplicate measurements.

\section{Conclusions}

Iopromide could not be degraded by $\mathrm{Cl}_{2}$ or PS oxidation alone, but could be degraded by $\mathrm{UV}$ irradiation, $\mathrm{UV} / \mathrm{Cl}_{2}$, and $\mathrm{UV} / \mathrm{PS}$ oxidation. The degradation of iopromide fitted pseudofirst-order kinetics with the rate constants calculated as $4.58( \pm 0.02) \times 10^{-2}, 2.20( \pm 0.01) \times 10^{-1}$, and $6.08( \pm 0.10) \times 10^{-2} \mathrm{~min}^{-1}$, in UV, UV $/ \mathrm{Cl}_{2}$, and $\mathrm{UV} / \mathrm{PS}$ systems, respectively. In $\mathrm{UV} / \mathrm{Cl}_{2}, \mathrm{k}_{\mathrm{obs}}$ was positively correlated with the initial concentration of $\mathrm{HOCl}$. The presence of $\mathrm{Cl}^{-}$had only a slight effect on iopromide degradation, while $\mathrm{Br}^{-}$inhibited it. The contributions of UV irradiation, $\bullet \mathrm{OH}$, and RCS to the degradation of iopromide were estimated to be $20.8 \%, 45.9 \%$, and $33.3 \%$, respectively. The degradation rate of iopromide first increased and then decreased with increasing $\mathrm{pH}$, with a maximum at $\mathrm{pH} 7$. During UV/PS oxidation, the rate constant of iopromide degradation increased significantly with an increase in PS concentration, while the $\mathrm{pH}$ had a negligible effect. Compared with UV irradiation, more C- and N-DBPs were produced in the $\mathrm{UV} / \mathrm{Cl}_{2}$ and $\mathrm{UV} / \mathrm{PS}$ systems, while much higher amounts of I-DBPs were produced in UV irradiation than in the other two systems. In order to better control the generation of carcinogenic and toxic I-DBPs, $\mathrm{Cl}_{2}$ or PS in combination with UV should be adopted for iopromide degradation, instead of UV alone, for providing safe drinking water to the public.

Supplementary Materials: The following supporting information can be downloaded at: https: / / www.mdpi.com/article/10.3390/w14030503/s1, Figure S1: UV visible spectrum of iopromide degradation during chlorine.

Author Contributions: Conceptualization, C.H. and Y.-L.L.; methodology, C.X.; software, Q.W.; validation, D.H. and Q.W.; formal analysis, Y.Z.; investigation, Y.Z.; data curation, Q.W.; writingoriginal draft preparation, C.H.; writing-review and editing, Y.-L.L., Y.Z. and L.X.; visualization, Q.W.; supervision, C.H. and Y.-L.L.; project administration, C.H.; funding acquisition, C.H. and Y.-L.L. All authors have read and agreed to the published version of the manuscript.

Funding: This research was funded by the Natural Science Foundation of China, China (No. 52170006), the Shanghai Committee of Science and Technology, China (Grant No. 17DZ2282800), and the Ministry of Science and Technology in Taiwan (110-2221-E-992-025).

Institutional Review Board Statement: Not applicable.

Informed Consent Statement: Not applicable.

Data Availability Statement: All analyzed data in this study have been included in the manuscript. 
Conflicts of Interest: The authors declare no conflict of interest. The funders had no role in the design of the study; in the collection, analyses, or interpretation of data; in the writing of the manuscript, or in the decision to publish the results.

\begin{abstract}
Abbreviations
ICM: iodinated X-ray contrast media; $\mathrm{UV} / \mathrm{Cl}_{2}$ : ultraviolet/chlorination; UV/PS: UV/persulfate; DBPs: disinfection by-products; C-DBPs: carbonated DBPs; N-DBPs: nitrogenated DBPs; I-DBPs: iodinated DBPs; I-THMs: iodinated trihalomethanes; I-Acids: iodo-acids; AOPs: advanced oxidation processes; TBA: tert-butanol; EtOH: ethanol; MtBE: methyl tert-butyl ether; CF: chloroform; DCAN: dichloroacetonitrile; TCAN: trichloroacetonitrile; TCNM: trichloronitromethane; 1,1,1-TCP: 1,1,1trichloroacetone; HPLC: high-performance liquid chromatography; GC: gas chromatography; DPD: N, N-diethyl-p-phenylenediamine.
\end{abstract}

\title{
References
}

1. Wu, Y.; Zhu, S.; Zhang, W.; Bu, L.; Zhou, S. Comparison of diatrizoate degradation by UV/chlorine and UV/chloramine processes: Kinetic mechanisms and iodinated disinfection byproducts formation. Chem. Eng. J. 2019, 375, 121972. [CrossRef]

2. Pérez, S.; Barceló, D. Fate and occurrence of X-ray contrast media in the environment. Anal. Bioanal. Chem. 2007, 387, 1235-1246. [CrossRef] [PubMed]

3. Duirk, S.E.; Lindell, C.; Cornelison, C.C.; Kormos, J.; Ternes, T.A.; Attene-Ramos, M.; Osiol, J.; Wagner, E.D.; Plewa, M.J.; Richardson, S.D. Formation of Toxic Iodinated Disinfection By-Products from Compounds Used in Medical Imaging. Environ. Sci. Technol. 2011, 6845-6854. [CrossRef] [PubMed]

4. Schulz, M.; Löffler, D.; Wagner, M.; Ternes, T.A. Transformation of the X-ray contrast medium iopromide in soil and biological wastewater treatment. Environ. Sci. Technol. 2008, 42, 7207-7217. [CrossRef]

5. Wang, Z.; Wang, X.; Yuan, R.; Xiao, D. Resolving the kinetic and intrinsic constraints of heat-activated peroxydisulfate oxidation of iopromide in aqueous solution. J. Hazard. Mater. 2020, 384, 121281. [CrossRef] [PubMed]

6. Müller, J.; Jewell, K.S.; Schulz, M.; Hermes, N.; Ternes, T.A.; Drewes, J.E.; Hübner, U. Capturing the oxic transformation of iopromide-A useful tool for an improved characterization of predominant redox conditions and the removal of trace organic compounds in biofiltration systems? Water Res. 2019, 152, 274-284. [CrossRef]

7. Cui, H.; de Angelis, M.H.; Schröder, P. Iopromide exposure in Typha latifolia L.: Evaluation of uptake, translocation and different transformation mechanisms in planta. Water Res. 2017, 122, 290-298. [CrossRef]

8. Jeong, C.H.; Machek, E.J.; Shakeri, M.; Duirk, S.E.; Ternes, T.A.; Richardson, S.D.; Wagner, E.D.; Plewa, M.J. The impact of iodinated X-ray contrast agents on formation and toxicity of disinfection by-products in drinking water. J. Environ. Sci. 2017, 58, 173-182. [CrossRef]

9. Steger-Hartmann, T.; Länge, R.; Schweinfurth, H. Environmental risk assessment for the widely used iodinated X-ray contrast agent iopromide (Ultravist). Ecotox. Environ. Saf. 1999, 42, 274-281. [CrossRef]

10. Plewa, M.J.; Wagner, E.D.; Richardson, S.D.; Thruston, A.D.; Woo, Y.T.; McKague, A.B. Chemical and biological characterization of newly discovered iodoacid drinking water disinfection byproducts. Environ. Sci. Technol. 2004, 38, 4713-4722. [CrossRef]

11. Richardson, S.D.; Plewa, M.J.; Wagner, E.D.; Schoeny, R.; Demarini, D.M. Occurrence, genotoxicity, and carcinogenicity of regulated and emerging disinfection byproducts in drinking water: A review and roadmap for research. Mutat. Res. 2007, 636, 178242. [CrossRef] [PubMed]

12. Xu, Z.; Li, X.; Hu, X.; Yin, D. Distribution and relevance of iodinated X-ray contrast media and iodinated trihalomethanes in an aquatic environment. Chemosphere 2017, 184, 253-260. [CrossRef] [PubMed]

13. Ackerson, N.O.B.; Machek, E.J.; Killinger, A.H.; Crafton, E.A.; Kumkum, P.; Liberatore, H.K.; Plewa, M.J.; Richardson, S.D.; Ternes, T.A.; Duirk, S.E. Formation of DBPs and halogen-specific TOX in the presence of iopamidol and chlorinated oxidants. Chemosphere 2018, 202, 349-357. [CrossRef] [PubMed]

14. Wendel, F.M.; Eversloh, C.L.; Machek, E.J.; Duirk, S.E.; Plewa, M.J.; Richardson, S.D.; Ternes, T.A. Transformation of iopamidol during chlorination. Environ. Sci. Technol. 2014, 48, 12689-12697. [CrossRef]

15. Velo-Gala, I.; López-Peñalver, J.J.; Sánchez-Polo, M.; Rivera-Utrilla, J. Comparative study of oxidative degradation of sodium diatrizoate in aqueous solution by $\mathrm{H}_{2} \mathrm{O}_{2} / \mathrm{Fe}^{2+}, \mathrm{H}_{2} \mathrm{O}_{2} / \mathrm{Fe}^{3+}$, $\mathrm{Fe}(\mathrm{VI})$ and $\mathrm{UV}, \mathrm{H}_{2} \mathrm{O}_{2} / \mathrm{UV}, \mathrm{K}_{2} \mathrm{~S}_{2} \mathrm{O}_{8} / \mathrm{UV}$. Chem. Eng. J. 2014, 241, 504-512. [CrossRef]

16. Li, J.; Jiang, J.; Pang, S.; Yang, Y.; Sun, S.; Wang, L.; Wang, P. Transformation of X-ray contrast media by conventional and advanced oxidation processes during water treatment: Efficiency, oxidation intermediates, and formation of iodinated byproducts. Water Res. 2020, 185, 116234. [CrossRef]

17. Dong, H.; Qiang, Z.; Hu, J.; Qu, J. Degradation of chloramphenicol by UV/chlorine treatment: Kinetics, mechanism and enhanced formation of halonitromethanes. Water Res. 2017, 121, 178-185. [CrossRef]

18. Kong, X.; Jiang, J.; Ma, J.; Yang, Y.; Pang, S. Comparative investigation of X-ray contrast medium degradation by UV/chlorine and $\mathrm{UV} / \mathrm{H}_{2} \mathrm{O}_{2}$. Chemosphere 2018, 193, 655-663. [CrossRef] 
19. Duan, X.; He, X.; Wang, D.; Mezyk, S.P.; Otto, S.C.; Marfil-Vega, R.; Mills, M.A.; Dionysiou, D.D. Decomposition of iodinated pharmaceuticals by UV-254 nm-assisted advanced oxidation processes. J. Hazard. Mater. 2017, 323, 489-499. [CrossRef]

20. Zhou, L.; Ferronato, C.; Chovelon, J.M.; Sleiman, M.; Richard, C. Investigations of diatrizoate degradation by photo-activated persulfate. Chem. Eng. J. 2017, 311, 28-36. [CrossRef]

21. APHA. Standard Methods for the Examination of Water and Wastewater; American Public Health Association: Washington, DC, USA, 1998.

22. Liang, C.; Huang, C.; Mohanty, N.; Kurakalva, R.M. A rapid spectrophotometric determination of persulfate anion in ISCO. Chemosphere 2008, 73, 1540-1543. [CrossRef] [PubMed]

23. USEPA. Determination of Chlorination Disinfection Byproducts, Chlorinated Solvents, and Halogenated Pesticides/herbicides in Drinking Water by Liquid-Liquid Extraction and Gas Chromatography with Electron-Capture Detection; USEPA: Cincinnati, OH, USA, 1995.

24. Zhang, B.; Wang, X.; Fang, Z.; Wang, S.; Shao, C.; Pan, B. Unravelling molecular transformation of dissolved effluent organic matter in $\mathrm{UV} / \mathrm{H}_{2} \mathrm{O}_{2}, \mathrm{UV} /$ persulfate, and UV/chlorine processes based on FT-ICR-MS analysis. Water Res. 2021, $199,117158$. [CrossRef] [PubMed]

25. Lee, M.; Wang, W.; Xu, Z.; Ye, B.; Wu, Q.; Hu, H. The application of UV/PS oxidation for removal of a quaternary ammonium compound of dodecyl trimethyl ammonium chloride (DTAC): The kinetics and mechanism. Sci. Total Environ. 2019, 655, 1261-1269. [CrossRef] [PubMed]

26. Fang, J.; Fu, Y.; Shang, C. The Roles of Reactive Species in Micropollutant Degradation in the UV/Free Chlorine System. Environ. Sci. Technol. 2014, 48, 1859-1868. [CrossRef] [PubMed]

27. Buxton, G.V.; Greenstock, C.L.; Helman, W.P.; Ross, A.B. Critical review of rate constants for reactions of hydrated electrons, hydrogen atoms and hydroxyl radicals $\left(\bullet \mathrm{OH} / \bullet \mathrm{O}^{-}\right)$in aqueous solution. J. Phys. Chem. Ref. Data 1988, 17, 513-886. [CrossRef]

28. Anipsitakis, G.P.; Dionysiou, D.D. Radical Generation by the Interaction of Transition Metals with Common Oxidants. Environ. Sci. Technol. 2004, 38, 3705-3712. [CrossRef] [PubMed]

29. Jeong, J.; Jung, J.; Cooper, W.J.; Song, W. Degradation mechanisms and kinetic studies for the treatment of X-ray contrast media compounds by advanced oxidation/reduction processes. Water Res. 2010, 44, 4391-4398. [CrossRef]

30. Zhu, T.; Deng, J.; Zhu, S.; Cai, A.; Ye, C.; Ling, X.; Guo, H.; Wang, Q.; Li, X. Kinetic and mechanism insights into the degradation of venlafaxine by UV/chlorine process: A modelling study. Chem. Eng. J. 2021, 431, 133473. [CrossRef]

31. Merouani, S.; Hamdaoui, O.; Alghyamah, A.; Bouhelassa, M. Influence of processing conditions on the synergism between UV irradiation and chlorine toward the degradation of refractory organic pollutants in UV/chlorine advanced oxidation system. Sci. Total Environ. 2020, 736, 139623.

32. Watts, M.J.; Linden, K.G. Chlorine photolysis and subsequent $\cdot \mathrm{OH}$ radical production during UV treatment of chlorinated water. Water Res. 2007, 41, 2871-2878. [CrossRef]

33. Kong, X.; Jiang, J.; Ma, J.; Yang, Y.; Liu, W.; Liu, Y. Degradation of atrazine by UV/chlorine: Efficiency, influencing factors, and products. Water Res. 2016, 90, 15-23. [CrossRef] [PubMed]

34. Gao, Z.; Lin, Y.; Xu, B.; Pan, Y.; Xia, S.; Gao, N.; Zhang, T.; Chen, M. Degradation of acrylamide by the UV/chlorine advanced oxidation process. Chemosphere 2017, 187, 268-276. [CrossRef]

35. Chen, L.; Cai, T.; Cheng, C.; Xiong, Z.; Ding, D. Degradation of acetamiprid in UV/ $\mathrm{H}_{2} \mathrm{O}_{2}$ and UV/persulfate systems: A comparative study. Chem. Eng. J. 2018, 351, 1137-1146. [CrossRef]

36. Gao, Y.; Gao, N.; Deng, Y.; Yang, Y.; Ma, Y. Ultraviolet (UV) light-activated persulfate oxidation of sulfamethazine in water. Chem. Eng. J. 2012, 195, 248-253. [CrossRef]

37. Neta, P.; Grodkowski, J.; Ross, A.B. Rate Constants for Reactions of Aliphatic Carbon-Centered Radicals in Aqueous Solution. J. Phys. Chem. Ref. Data 1996, 25, 709. [CrossRef]

38. Liu, H.; Hou, Z.; Li, Y.; Lei, Y.; Xu, Z.; Gu, J.; Tian, S. Modeling degradation kinetics of gemfibrozil and naproxen in the UV/chlorine system: Roles of reactive species and effects of water matrix. Water Res. 2021, 202, 117445. [CrossRef]

39. Grebel, J.E.; Pignatello, J.J.; Mitch, W.A. Effect of Halide Ions and Carbonates on Organic Contaminant Degradation by Hydroxyl Radical-Based Advanced Oxidation Processes in Saline Waters. Environ. Sci. Technol. 2010, 44, 6822-6828. [CrossRef]

40. Yang, T.; Mai, J.; Wu, S.; Liu, C.; Tang, L.; Mo, Z.; Zhang, M.; Guo, L.; Liu, M.; Ma, J. UV/chlorine process for degradation of benzothiazole and benzotriazole in water: Efficiency, mechanism and toxicity evaluation. Sci. Total Environ. 2021, 760, 144304 [CrossRef]

41. Gao, Y.; Zhang, J.; Li, C.; Tian, F.; Gao, N. Comparative evaluation of metoprolol degradation by UV/chlorine and UV/ $\mathrm{H}_{2} \mathrm{O}_{2}$ processes. Chemosphere 2020, 243, 125325. [CrossRef]

42. Wu, Z.; Guo, K.; Fang, J.; Yang, X.; Xiao, H.; Hou, S.; Kong, X.; Shang, C.; Yang, X.; Meng, F.; et al. Factors affecting the roles of reactive species in the degradation of micropollutants by the UV/chlorine process. Water Res. 2017, 126, 351-360. [CrossRef]

43. Qin, L.; Lin, Y.; Xu, B.; Hu, C.; Tian, F.; Zhang, T.; Zhu, W.; Huang, H.; Gao, N. Kinetic models and pathways of ronidazole degradation by chlorination, UV irradiation and UV/chlorine processes. Water Res. 2014, 65, 271-281. [CrossRef] [PubMed]

44. Dong, Z.; Xu, B.; Hu, C.; Zhang, T.; Tang, Y.; Pan, Y.; Mohamed, G.E.D.; Xian, Q.; Gao, N. The application of UV-C laser in persulfate activation for micropollutant removal: Case study with iodinated X-ray contrast medias. Sci. Total Environ. 2021, 779, 146340. [CrossRef] [PubMed]

45. Wang, L.; Kong, D.; Ji, Y.; Lu, J.; Yin, X.; Zhou, Q. Transformation of iodide and formation of iodinated by-products in heat activated persulfate oxidation process. Chemosphere 2017, 181, 400-408. [CrossRef] [PubMed] 